\title{
The Effects of Minimum Wages on Employment: Theory and Evidence from Britain
}

\author{
Richard Dickens, London School of Economics \\ Stephen Machin, University College London \\ Alan Manning, London School of Economics
}

Recent work on the economic effects of minimum wages has stressed that the standard economic model, where increases in minimum wages depress employment, is not supported by empirical work in some labor markets. We present a general theoretical model whereby employers have some degree of monopsony power, which allows minimum wages to have the conventional negative impact on employment but which also allows for a neutral or positive impact. Studying the industry-based British Wages Councils between 1975 and 1992, we find that minimum wages significantly compress the distribution of earnings but do not have a negative impact on employment.

\section{Introduction}

There has been a considerable resurgence of interest in the economics of the minimum wage following the recent publication of a number of

We would like to thank Joe Altonji, Danny Blanchflower, Ken Burdett, David Card, Alan Krueger, Bruce Meyer, Steve Pischke, and participants in seminars at Barcelona (Pompeu Fabra), Dartmouth, Guelph, Hull, London School of Economics, Manchester, McMaster, Melbourne, Massachusetts Institute of Technology, Northwestern, Pennsylvania, and Princeton for helpful comments, Professor J. J. Hughes for providing an insight into the rate-fixing discussions of the Wages Councils; the Economic and Social Research Council ESRC for financial support; and the Department of Employment for giving us access to the New Earnings Survey microdata. The results reported and the views expressed here do not necessarily reflect those of the Department of Employment.

[Journal of Labor Economics, 1999, vol. 17, no. 1]

(C) 1999 by The University of Chicago. All rights reserved.

0734-306X/99/1701-0007\$02.50 
papers (Card 1992a, 1992b; Katz and Krueger 1992; Card, Katz, and Krueger 1994; Card and Krueger 1994; Machin and Manning 1994; Bernstein and Schmitt 1998; Card and Krueger 1998) and a much discussed book (Card and Krueger 1995) that, contrary to the accepted wisdom of the standard competitive model of the labor market, have found zero or even positive effects of minimum wages on employment. Other recent work, however, has presented results in line with the orthodox approach (Deere, Murphy, and Welch 1995; Kim and Taylor 1995; Neumark and Wascher 1995). At present, explaining the divergence between the results from these different studies is something of a puzzle.

The main economic model that could potentially explain the nonorthodox results is the monopsony model. But monopsony is currently not a popular model of the labor market. For example, it has been claimed that "there is little evidence that it is important in modern-day low-wage labor markets" (Brown, Gilroy, and Kohen 1982, p. 489). ${ }^{1}$ This viewpoint is based on the company-town example of monopsony that is cited in many labor economics textbooks. However, we would argue that monopsony from labor market frictions may be more common than this: for example, in most labor markets employers that cut wages do not instantaneously lose all their workers, so the supply of labor to a firm is not perfectly elastic, and firms therefore possess some monopsony power. These ideas can be given more formal expression: search models of the labor market (like Burdett and Mortensen 1998) provide some support for the view that it is not difficult to construct reasonable theoretical models of the labor market where employers have some monopsony power in both the short and the long run.

In this article we present a simple model of the labor market in which all firms potentially have some monopsony power. We think this model is a good starting point for thinking about the effect of minimum wages on employment as this effect is not determined a priori as it is when competitive models are used. In the next section of this article we outline this theoretical model of the labor market. In Section III, we look in some detail at the wage structure and employment effects of the minimum rates of pay set by the British Wages Councils using panel data from the 1970s through to the 1990s (for some of our earlier work on British minimum wages, see Dickens, Machin, and Manning [1994], which presents a more detailed theoretical framework including model simulations; Machin and Manning [1994], for some empirical work using different data; and Machin and Manning [1996], who discuss the policy implications of recent minimum wage research). Section IV concludes.

\footnotetext{
${ }^{1}$ Exceptions are sometimes noted, with probably the most commonly cited exception being the U.S. market for nurses (see Sullivan 1989).
} 


\section{The Model}

In this section we present a simple model of a monopsonistically competitive labor market to provide a framework for thinking about the effect of minimum wages. ${ }^{2}$ Immediately, one might wonder what this analysis adds to the textbook model of a single monopsonistic firm. We think its contribution is twofold. First, it brings out the important distinction between the elasticity of labor supply to an individual firm (which determines their monopsony power) and the elasticity of labor supply to the market as a whole (which is more important in determining the employment effects of the minimum wage). Second, it allows an analysis of the way in which different firms in the same market are differentially affected by the minimum wage.

Assume firm $i$ in the market has a marginal revenue product of labor curve given by

$$
\mathrm{MRPL}_{i}=M\left(L_{i}, A_{i}\right)
$$

where $L$ is employment and $A$ is a shock to the MRPL reflecting demand or productivity shocks. Assume that $M$ is a decreasing function of $L$ and an increasing function of $A$.

On the supply side we assume that the labor supply curve facing firm $i$ is

$$
L_{i}=f\left(B_{i}, W_{i} / W\right) \cdot L(W),
$$

where $L$ is the aggregate labor supply in the industry that we assume to be positively related to the average wage in the industry (e.g., because workers need to acquire industry-specific skills before entering an industry). Equation (2) is analogous to the Dixit and Stiglitz (1977) specification of the demand curve facing an individual firm in models of monopolistic competition: in (2) the share of total labor supply in industry $i$ is determined by the relative wage and a firm-specific labor supply shock, $B_{i}$, which could represent differences in the nonpecuniary attractiveness of work in different firms or differences in the average quality of labor across firms (in which case it is likely to be positively correlated with the shock to the MRPL curve). If the labor market is perfectly competitive, then the function $f$ will be infinitely elastic with respect to the relative wage. If it is not infinitely elastic, the market is, to some extent, monopsonistic. As we have emphasized in the introduction, we think of

\footnotetext{
${ }^{2}$ An explicit version of this model with log-linear demand and supply curves and log-normally distributed shocks is presented in Dickens, Machin, and Manning (1994).
} 
the source of the monopsony power of employers as being labor market frictions. ${ }^{3}$

Inverting (2) leads to the following expression for the wage that firm $i$ must pay given its employment, its specific shock, $B_{i}$, and the aggregate wage

$$
W_{i}=W^{s}\left(W, B_{i}, L_{i}\right)
$$

Note that the effect of the average wage on the own wage is ambiguous. If a high average wage attracts a lot of workers into the industry, then it is possible that the wage this firm needs to pay to attract workers will actually fall. The effect of the average wage on the aggregate labor supply is also important in determining the likely employment effect of the minimum wage. If aggregate labor supply is inelastic, then, although an individual firm can raise its labor supply by raising its wage, each individual firm is a monopsonist paying workers a wage below the value of their marginal product, so that aggregate employment cannot be raised by raising the minimum wage.

Now consider the equilibrium when there are no minimum wages. Suppose that firms choose wages (or equivalently employment) to maximize profits. ${ }^{4}$ Then each firm chooses a level of employment where the MRPL equals the marginal cost of labor so that

$$
M\left(L_{i}, A_{i}\right)=W_{i}+L_{i} \cdot \frac{\delta W_{i}}{\delta L_{i}}=(1+\theta) \cdot W_{i},
$$

where $\theta$ is the elasticity of the wage with respect to employment from (3). In general, $\theta$ will depend on $\left(W, B_{i}, L_{i}\right)$. Equating (4) and (3) gives employment in firm $i$ as

$$
M\left(L_{i}, A_{i}\right)=(1+\theta) \cdot W^{s}\left(W, B_{i}, L_{i}\right) .
$$

\footnotetext{
${ }^{3}$ Some arguments along these lines are presented in more detail in Machin and Manning (1994) and Machin, Manning, and Woodland (1993). Search related frictions may also be used to underpin the notion of an upward-sloping firm labor supply schedule. It is also evident that one can debate whether this monopsony power exists only in the short run. Our model, which is static for analytical convenience, cannot address this issue, but because workers are continually leaving and entering the labor market, it is not unreasonable to believe that some firms do have some monopsony power in the long run.

${ }^{4}$ An alternative approach could be to set up the model as a bilateral monopoly problem where the providers of labor services also have some monopoly power (e.g., as in MacLeod and Malcomson 1993). We do not pursue this here, but similar results would be obtained if worker bargaining power is small.
} 
Write employment as $L\left(A_{i}, B_{i}, W\right)$. Given employment, the wage can be found from (3):

$$
W_{i}=W^{s}\left(W, B_{i}, L\left(A_{i}, B_{i}, W\right)\right) .
$$

One can then close the model by taking expectations of (6) to solve for the average wage, $W$.

In this model firm-specific shocks are the source of heterogeneity, and a typical pattern is that high-wage firms have higher employment (as in the well-documented existence of positive employer-size wage effects as in, e.g., Brown and Medoff [1989]). Revenue shocks, $A_{i}$, have a positive effect on employment while supply shocks, $B_{i}$, will generally have a negative effect (a sufficient condition for which is that $\theta$ is constant). In contrast, both $A_{i}$ and $B_{i}$ are positively related to wages although, as we would expect, $A_{i}$ only has an effect to the extent that the labor market is not perfectly competitive. ${ }^{5}$ The joint distribution of wages and employment then depends on the joint distribution of $\left(A_{i}, B_{i}\right)$ across firms. For what follows it is helpful to make the assumption that changes in the average wage do not affect the ranking of firms in terms of wages (a sufficient, but not necessary, condition for this is that all functions are isoelastic).

Let us denote the wage chosen by firm $i$ in the absence of a minimum wage by $W_{0 i}$ : we will refer to this as the initial wage. Now consider what happens if a minimum wage of $W^{*}$ is introduced. A firm can now be in one of three qualitatively distinct regimes as depicted in figure 1 . In the first, which we will call the "unconstrained regime" and corresponds to $M R P L_{1}$ in the figure, the firm pays a wage above the minimum and the employment, and wage rates of (5) and (6) continue to be relevant. Note that if $W^{s}$ depends on $W$, the change in the average wage caused by the minimum wage will mean that the set of firms initially paying above $W$ * will not be the same as the ones now paying above $W *$ and that although the unconstrained firms pay above the minimum they are still affected by it. Which firms will be in this regime? Given our assumptions, it must be the case that it is the firms with the highest initial wages, $W_{o i}$, that are in this regime. So firms with $W_{0 i} \geq W_{+}$for some $W_{+}$will be in this regime.

For firms with $W_{0 i}$ slightly below $W_{+}$(e.g., with marginal productivity schedule $\mathrm{MRPL}_{2}$ in fig. 1 ), it is optimal to pay $W^{*}$ and accept all workers forthcoming at this wage. We refer to these as "supply-constrained"

\footnotetext{
${ }^{5}$ There is a lot of empirical evidence that wages do depend on variables related to firm and industry productivity, even in the nonunion sector (e.g., Dickens and Katz 1987; Nickell and Wadhwani 1990) which is consistent with the monopsony model.
} 


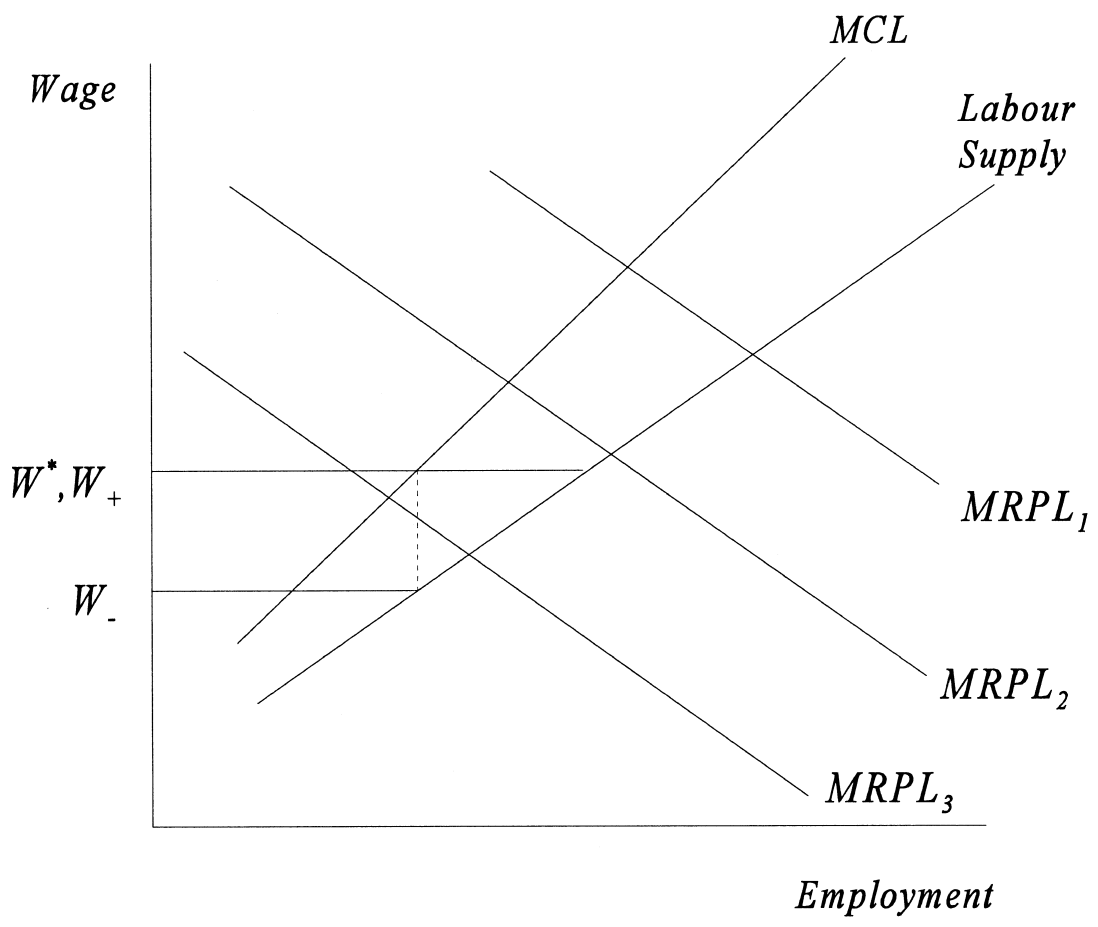

FIG. 1.- The three qualitatively distinct regimes

firms. Their employment can be found by substituting $W_{i}=W^{*}$ in (3). As they are on their labor supply curves, employment in these firms will, given $W$, be higher with the minimum wage than without.

But if the initial wage is sufficiently low (i.e., $W_{0 i}$ is less than some $W_{-}$) then the firm will be in a situation where it is not profitable for the firm to employ all the workers forthcoming at $W^{*}$. We will refer to these firms as "demand constrained" (e.g., on $\mathrm{MRPL}_{3}$ in fig. 1). These firms choose employment so that $\mathrm{MRPL}_{i}=W^{*}$ so that employment will be on the labor demand curve. The employment level of firms in this regime will rise with the introduction of the minimum wage if $W_{0 i}$ is close to $W_{-}$but will fall if $W_{0 i}$ is very low.

One can neatly summarize the employment effects of a minimum wage by considering figure $2 .^{6}$ Assume, for simplicity that the average wage does not affect $W^{s}$. The line $L L$ gives the average relationship between employment and $W_{0 i}$ before the introduction of a minimum wage. Suppose a minimum wage is introduced that induces a cut-off point $W_{+}$

${ }^{6}$ For more detail on this kind of model with specific functional form assumptions and some model simulations see Dickens, Machin, and Manning (1994). 


\section{Employment}

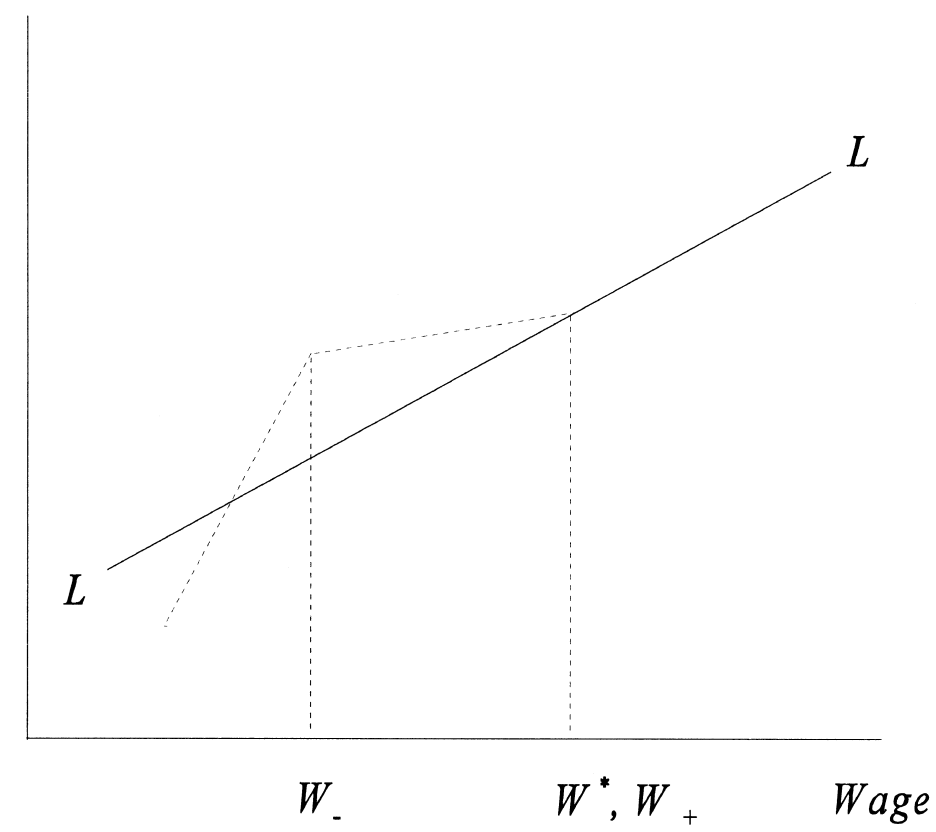

FIG. 2.-The effect of the minimum wage on employment

between the unconstrained and supply-constrained regimes. Only employment in firms with $W_{0 i}$ below $W_{+}$are affected; let us denote the new level of employment in these firms by the dotted line. It should be obvious from figure 2 that we cannot tell, a priori, the effect on total employment unless $\theta=0$, where the labor market is perfectly competitive. In this case the supply-constrained regime disappears and all demand-constrained firms suffer employment losses. The picture of figure 2 needs modification if the average wage affects employment in each firm, as $L L$ then depends on the minimum wage, but the basic ideas remain the same. In general, a minimum wage increase can at first raise employment, but there will eventually be a negative association, and the appropriate empirical question should be the point at which the sign of the relationship switches.

\footnotetext{
${ }^{7}$ In this kind of model, in which firms that would otherwise pay below the minimum wage come up to the minimum wage once it is imposed, there is an issue regarding noncompliance, especially for firms that would like to pay very low wages (see Ashenfelter and Smith 1979). The extent of noncompliance seems limited in the British data that we consider below as there are not many individuals paid below the minimum wage, even in the early 1990s when the minimum wage system was weaker than before (see the figures in Dickens and Manning [1995]).
} 
Figure 2 also has certain implications for the empirical investigation of the effect of minimum wages. For example, it is sometimes argued that looking at the effect on employment in the lowest-wage parts of the market relative to the higher-wage parts gives a good estimate of the impact of the minimum wage. But figure 2 suggests there is a serious potential bias in doing this, as we would expect the employment effect of minimum wages to be more negative in low-wage relative to highwage parts of the market, but this tells us little about the overall employment effect unless one can be sure that there is no employment effect in the high-wage parts, a condition that is unlikely to be satisfied in reality. So the model suggests that the impact of a minimum wage is likely to be spread across a wide range of the wage distribution in an uneven way.

\section{The Effect of Minimum Wages on Employment in Britain: The Wages Councils}

\section{A. The Wages Councils}

The Wages Councils were established by Winston Churchill in 1909 to protect the pay of workers in the so-called sweated trades. They set minimum wage rates in a number of different industries. Over the years, the number of industries covered first increased (to a peak of about 60 covered sectors in the early 1960s), then decreased, and by the early 1990s the 26 remaining Wages Councils set minimum wages for approximately 2.5 million workers in low-paid sectors (mostly in hotels and catering, retail, clothing manufacture, and hairdressing but also in a number of very small industries).

Each Wages Council consisted of an equal number of employer and worker representatives, plus a maximum of three independent members (nominated by the government of the day) who had the casting vote if an agreement was not reached. Until the 1986 Wages Act, the councils generally set a myriad of minimum wages differentiated by age, occupation, and region but since 1986 set only a single rate. The way in which the councils set minimum wages is an important institutional feature that underpins our empirical work. Our discussions with independent members who sat on the Wages Councils suggests that the method of minimum-wage fixing was generally rather crude, using only recent pay settlements and inflation figures and making no attempt to forecast future market conditions. ${ }^{8}$

\footnotetext{
${ }^{8}$ We would like to thank Professor J. J. Hughes for providing us with an insight into the internal workings of the Wages Councils when setting minimum rates. Hughes sat as an independent member on a number of Wages Councils, including the Retail Food and Waste Reclamation Councils. From his experience, ratesetting was essentially backward looking, using current inflation figures and other predated Wages Council agreements as a basis for rate fixing.
} 
The 1993 Trade Union Reform and Employment Rights Bill abolished the remaining 26 Councils so that from 1993 there were no minimum wages in operation in Britain (except in agriculture; see Dickens et al. 1995). One of the Conservative government's arguments for abolition was based on the claim that the minimum rates of pay set by the councils were bad for employment (see Dickens et al. 1993; Machin and Manning 1996).

\section{B. The Data}

The best source of information on workers covered by the Wages Councils is the annual New Earnings Survey (NES). This is an employerreported survey conducted in April based on an approximately 1\% sample of all employees who pay tax through the Pay-As-You-Earn (PAYE) income tax scheme. We have access to the data for the years from 1975 to 1992 and perform our empirical analysis on a panel of Wages Council industries over time.

There are two ways of identifying workers in Wages Council industries from the NES. First, employers are asked whether workers are covered by a Wages Council agreement. Second, we can use the detailed industrial and occupational information to work out who should be covered. Typically, the numbers obtained using the first method are less than the numbers obtained by the second method, and there seems to be some degree of misclassification. For this reason, we prefer the numbers obtained from the second method. ${ }^{9}$ Only the relatively large Wages Councils have enough workers in the NES for the data to be considered reliable; the ones used in this study are reported in table 1. A potential problem is that the 1986 Wages Act removed people under the age of 21 from the coverage of the Wages Councils. However, it seems that after 1986 the adult minimum rates still exerted an effect on youth wages (which is reminiscent of the U.S. finding of Katz and Krueger [1992], that the youth subminimum is rarely used), so we use total employment in the Wages Council industries in our empirical analysis.

A further concern is that the NES undersamples part-time workers, as workers only contribute to the PAYE scheme if they earn more than a certain amount ( $£ 66.50$ per week in 1994). So we also used employment figures from the Workforce in Employment survey published by the Department of Employment in the Employment Gazette (EG). These have the advantage that they include part-time workers but the disadvantage that the map between the industry classification and the Wages Councils is not perfect. Table 1 summarizes our employment data. We present average employment based on both NES and EG figures and the

\footnotetext{
${ }^{9}$ Despite this, some of our earlier work (Machin and Manning 1994) used the former numbers and reached similar conclusions to those reported below.
} 
Table 1

Summary of Wages Council Data

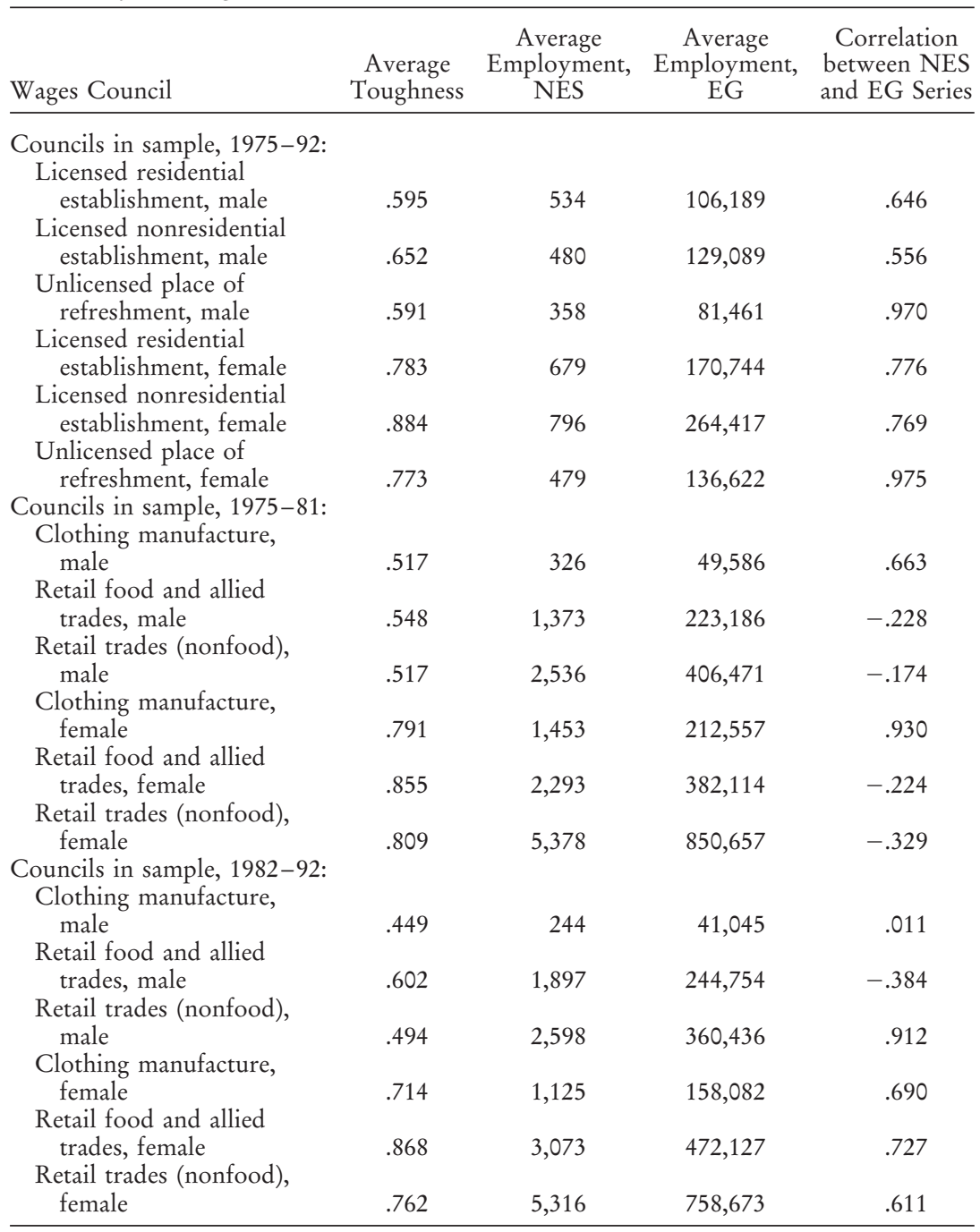

NOTE. - The 1975-81 and 1982-92 councils are treated separately as a consequence of the 1980 change in the Standard Industrial Classification (i.e., pre-1980 and post-1980 definitions did not match after the change), which was adopted in the New Earnings Survey data in 1982. NES refers to New Earnings Survey and EG to published Employment Gazette figures. Toughness is defined as the ratio of the minimum hourly wage to the average hourly wage.

correlation between the two. As can be seen, the correlation is low in some cases (though this only seems to be a problem for the councils we do not follow through the entire 1975-92 period), so it is important to check the strength of our results using both measures; we are careful to do this below. 


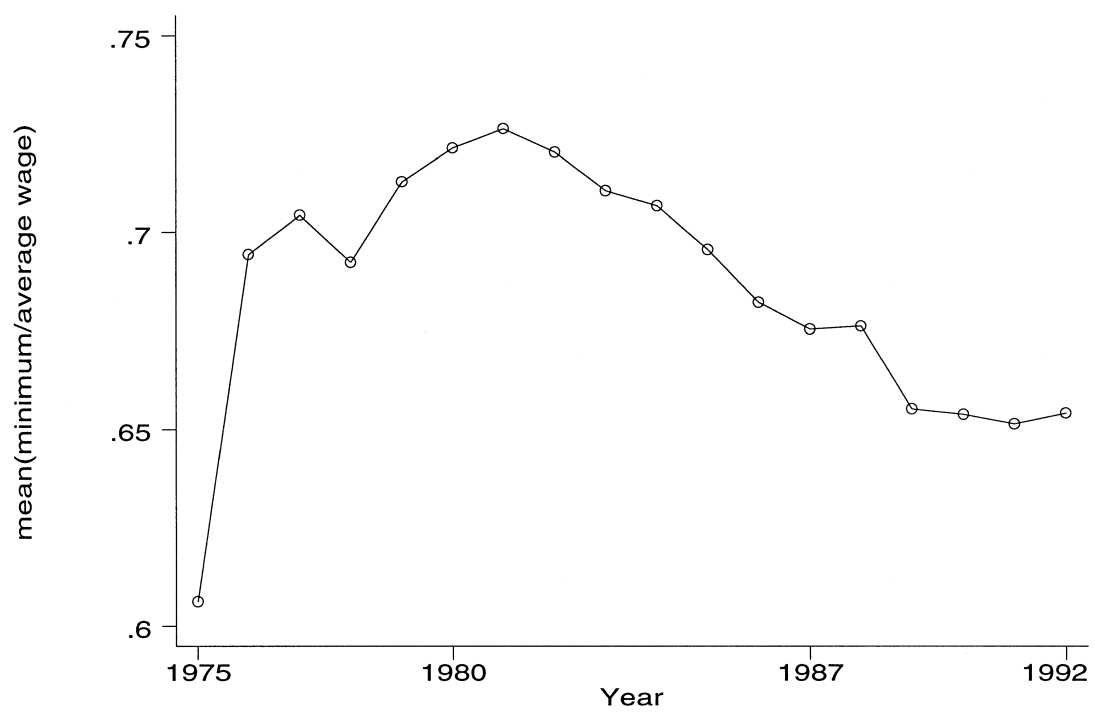

FIG. 3. - The toughness of the wages councils: the mean of ratio of minimum to average hourly earnings, 1975-92. Source: New Earnings Survey data.

For our wage variable we use the basic hourly wage. We use the ratio of the minimum to the average wage as our measure of the impact of the minimum wage: this is what we call toughness. After 1986 computation of toughness is straightforward as a single rate was set. Prior to that date, we use the lowest adult minimum rate in force. ${ }^{10}$ The average level of toughness for each Wages Council is reported in table 1 and mean toughness in each year is plotted in figure 3. As can be seen, toughness of the minimum wage increased in the 1970s but decreased in the 1980s with the arrival in 1979 of a government hostile to the idea of minimum wages.

\section{The Effect of the Wages Councils on the Wage Distribution}

In this section we investigate the effect of the minimum rates set by the Wages Councils on the distribution of wages. There are a number of reasons for being interested in this. First, some commentators have expressed doubts about whether the Wages Councils had any effect at all because of lack of enforcement. Second, we would like to have some

\footnotetext{
${ }^{10}$ We conducted robustness checks using the highest adult minimum rate to construct the toughness variable. The correlation between the two toughness measures is high, giving a correlation coefficient of .91 for $\log$ (toughness) and .72 for the change in $\log$ (toughness). We also used this alternative measure of toughness in our employment equations, and it gave qualitatively similar results.
} 
Table 2

Effects of Minimum Wages on the Wage Distribution

Dependent Variable: $\Delta i$ th Percentile/Average of log Real Hourly Earnings

Distribution

\begin{tabular}{lcc}
\hline Dependent Variable & $\begin{array}{c}\text { Coefficient (Standard Error) on } \\
\Delta \log (\text { Real Minimum Hourly Wage) }\end{array}$ & $\begin{array}{c}\text { Test for Serial } \\
\text { Correlation }\end{array}$ \\
\hline$\Delta$ tenth percentile & $.193(.082)$ & -1.168 \\
$\Delta$ twentieth percentile & $.242(.065)$ & -1.778 \\
$\Delta$ thirtieth percentile & $.217(.068)$ & -.707 \\
$\Delta$ fortieth percentile & $.126(.057)$ & -1.213 \\
$\Delta$ fiftieth percentile & $.089(.066)$ & -1.558 \\
$\Delta$ sixtieth percentile & $.040(.069)$ & -1.803 \\
$\Delta$ seventieth percentile & $-.001(.058)$ & 1.533 \\
$\Delta$ eightieth percentile & $.005(.069)$ & .229 \\
$\Delta$ ninetieth percentile & $.020(.083)$ & .300 \\
$\Delta$ average & $.114(.057)$ & -1.414 \\
\hline
\end{tabular}

NOTE.-Sample size is 198; estimation period is 1976-92. Regressions are weighted by employment in industry-year cell. Heteroskedastic consistent standard errors are in parentheses. Time dummies included in all specifications. Serial correlation test is an $N(0,1)$ statistic for first-differenced panel data models as described in Arellano and Bond (1991).

idea of the effect of the minimum wage on wages further up the wage distribution.

We investigated this by estimating first-differenced regressions of the log hourly wage at each decile in the earnings distribution on the log of the hourly minimum wage, together with year dummies (the regressions are weighted by the cell sizes in each industry-year cell). The results are reported in table 2. As would be expected, the effect of the minimum wage on earnings levels is strongest at the lowest deciles of the distribution. Effects are estimated to be insignificantly different from zero for the median and higher deciles in the distribution, indicating that the minimum has the effect of compressing the distribution of earnings. As the bottom row of the table testifies, there is also a positive significant impact on the average wage.

\section{The Effect of the Wages Councils on Employment:}

\section{Panel Data Estimates}

In this section we investigate the relationship between employment and minimum wages using our panel on the British Wages Councils between 1975 and 1992. For Wages Council $j$ in year $t$ the employment equation suggested by the theory above is $L_{j t}\left(A_{j t}, B_{j t}, W_{j t}^{*}\right)$, where employment depends on demand and supply shocks in the market as a whole and the minimum wage. We choose to normalize the minimum wage by the Wages Council average wage (to give what we call toughness, $W * / W)$ as there is growth in average wages over our sample so that a given minimum might be expected to have very different effects 
at different points of our sample. We operationalize the employment equation as

$$
\begin{aligned}
\log \left(L_{j t}\right)= & f_{j}+\delta_{1} \log \left(W_{j t}^{*} / W_{j t}\right)+\delta_{2} \text { TIME }_{t} \\
& +\delta_{3} \log \left(\text { SALES }_{j t}\right)+\delta_{4} \text { SECTOR }_{j t}+u_{j t}
\end{aligned}
$$

where $f_{j}$ is a council-specific fixed effect, TIME captures common macroeconomic effects, SALES is real sales, SECTOR denotes a set of linear trends for specific sectors, and $u$ is a random error.

Equation (7) forms the basis for the empirical work. We think of most supply shocks as coming from the aggregate labor market, so model these by including the macroeconomic effects and Wages Council dummies. Modeling demand shocks is more tricky, mainly because most Wages Council workers are employed in service-sector industries for which we have limited information on variables that shift the revenue function (e.g., prices). We follow two strategies to try to control for demand shifts. First, we have data on industry sales that will be related to the industry shocks, $A$, through the revenue function $R=A \cdot L^{\alpha}$ so we include (appropriately instrumented) sales variables in our employment functions. Second, we allow for different employment trends in the catering, clothing, and retail sectors to control for sector-specific employment changes.

Figure 4 presents a scatter plot of the log of employment changes against changes in the log of toughness. In the raw data there is an upwardsloping relationship, suggesting little support for the notion that minimum wages were bad for employment in the Wages Council industries between 1975 and 1992. However, as noted above, it is important to control for demand and supply shocks so we next consider the results derived from econometric models of employment.

In table 3 we present a set of results based on estimating variants of (7) in first-differences (to eliminate the fixed effects) using three different measures of employment. We report five specifications for each measure of employment that differ in their estimation method and in their inclusion of controls for supply and demand shocks.

The first five rows present results using the employment measure from the NES as the dependent variable. Row 1 is a simple least squares regression of the change in $\log$ (employment) on the change in log(toughness) plus a set of year dummies (to control for common macroeconomic effects). The coefficient on the toughness variable is estimated to be positive (and significantly different from zero at the $10 \%$ level) with a $t$-ratio of 1.74 . Hence, the basic correlation between employment changes and changes in the toughness of minimum wages is not in line with the conventional viewpoint.

The functional form of the toughness variable imposes equal and 


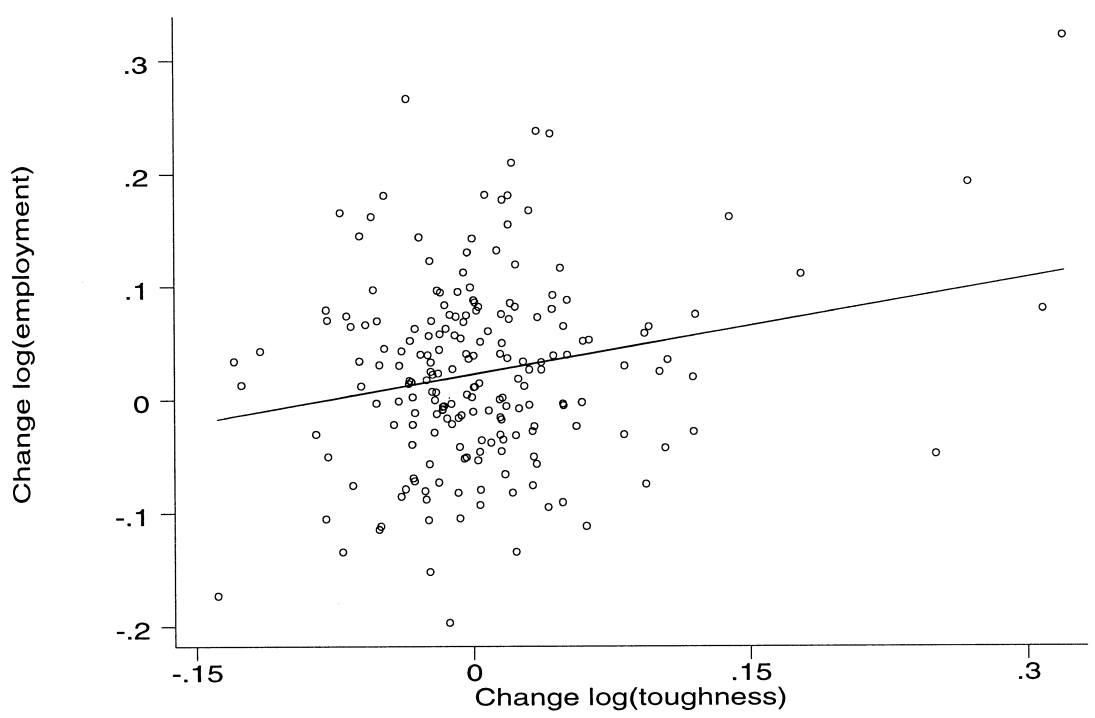

FIG. 4.-Changes in $\log$ (employment) and changes in $\log$ (toughness). Based on New Earnings Survey data described in table 1 . The regression line is from a regression of the change in $\log$ (employment) on the change in the $\log$ (minimum/average) (standard errors in brackets):

Change in $\log ($ employment $)=.022+.286$ Change in $\log ($ minimum/average $)$. (.006) (.125)

An analogous regression estimated by robust regression methods to downgrade the importance of potential outliers was

Change in $\log ($ employment $)=.020+.220$ change in $\log ($ minimum/average $)$. (.006) (.092)

opposite regression coefficients on the minimum and average wage variables in the estimated employment equation. But if the real minimum and the real average wage are included as separate arguments, their coefficients and standard errors are estimated as .280 (.161) and -.135 (.164), respectively. A formal test of their restriction to the toughness variable has a $p$-value of 0.465 , suggesting that the restriction is not rejected by the data.

The next two rows of table 3 attempt to control for the effects of demand shocks using a number of different variables (sector-specific trends and sales growth). In row 2 we include dummy variables for clothing and retail councils (which allow for different employment trends in these sectors). Their estimated coefficients are negative and significant, suggesting slower employment growth over the sample period than in the catering sector (the base group). The coefficient on $\log$ (toughness) is reduced slightly by their inclusion but remains positive with a $t$-ratio of about 1.4. 
Table 3

Employment Equations in 18 Covered Wages Council Industries, 1978-92

\begin{tabular}{|c|c|c|c|c|c|}
\hline $\begin{array}{l}\text { Employment Variable/ } \\
\text { Method of Estimation }\end{array}$ & $\Delta \log (\text { Toughness })_{j t}$ & $\begin{array}{l}\text { Retail } \\
\text { Sector }\end{array}$ & $\begin{array}{l}\text { Clothing } \\
\text { Sector }\end{array}$ & $\begin{array}{c}\Delta \log (\text { Sales })_{j t} \\
\text { (Instrumented) }\end{array}$ & $\begin{array}{c}\text { Serial } \\
\text { Correlation }\end{array}$ \\
\hline \multicolumn{6}{|l|}{$\begin{array}{l}\text { NES employment, } \\
\text { toughness not } \\
\text { instrumented: }\end{array}$} \\
\hline (1) & $\begin{array}{l}.178 \\
(.102)\end{array}$ & $\begin{array}{l}\ldots \\
\ldots\end{array}$ & $\begin{array}{l}\ldots \\
\ldots\end{array}$ & $\begin{array}{l}\ldots \\
\ldots\end{array}$ & 1.269 \\
\hline$(2)$ & $\begin{array}{l}.139 \\
(.100)\end{array}$ & $\begin{array}{l}-.019 \\
(.007)\end{array}$ & $\begin{array}{l}-.069 \\
(.007)\end{array}$ & $\begin{array}{l}\ldots \\
\ldots\end{array}$ & .205 \\
\hline (3) & $\begin{array}{l}.275 \\
(.144)\end{array}$ & $\begin{array}{r}-.009 \\
(.007)\end{array}$ & $\begin{array}{l}-.008 \\
(.014)\end{array}$ & $\begin{array}{l}.876 \\
(.237)\end{array}$ & -1.255 \\
\hline \multicolumn{6}{|l|}{$\begin{array}{l}\text { NES employment, } \\
\text { toughness } \\
\text { instrumented: }\end{array}$} \\
\hline (4) & $\begin{array}{l}.282 \\
(.194)\end{array}$ & $\begin{array}{r}-.010 \\
(.007)\end{array}$ & $\begin{array}{l}-.013 \\
(.013)\end{array}$ & $\begin{array}{l}.760 \\
(.223)\end{array}$ & -1.100 \\
\hline$(5)$ & $\begin{array}{l}.330 \\
(.196)\end{array}$ & $\begin{array}{l}-.009 \\
(.006)\end{array}$ & $\begin{array}{l}-.009 \\
(.013)\end{array}$ & $\begin{array}{l}.810 \\
(.228)\end{array}$ & -1.177 \\
\hline \multicolumn{6}{|l|}{$\begin{array}{l}\text { NES employee hours, } \\
\text { toughness not } \\
\text { instrumented: }\end{array}$} \\
\hline (6) & $\begin{array}{l}.240 \\
(.138)\end{array}$ & $\begin{array}{l}\ldots \\
\ldots\end{array}$ & $\begin{array}{l}\ldots \\
\ldots\end{array}$ & $\begin{array}{l}\cdots \\
\ldots\end{array}$ & 1.111 \\
\hline (7) & $\begin{array}{l}.200 \\
(.143)\end{array}$ & $\begin{array}{l}-.019 \\
(.007)\end{array}$ & $\begin{array}{l}-.072 \\
(.011)\end{array}$ & $\begin{array}{l}\ldots \\
\ldots\end{array}$ & .828 \\
\hline (8) & $\begin{array}{l}.197 \\
(.150)\end{array}$ & $\begin{array}{l}-.013 \\
(.009)\end{array}$ & $\begin{array}{l}-.007 \\
(.015)\end{array}$ & $\begin{array}{l}.941 \\
(.177)\end{array}$ & .246 \\
\hline \multicolumn{6}{|l|}{$\begin{array}{l}\text { NES employee hours, } \\
\text { toughness } \\
\text { instrumented: }\end{array}$} \\
\hline (9) & $\begin{array}{l}.047 \\
(.189)\end{array}$ & $\begin{array}{l}-.017 \\
(.009)\end{array}$ & $\begin{array}{l}-.014 \\
(.013)\end{array}$ & $\begin{array}{l}.840 \\
(.169)\end{array}$ & .490 \\
\hline$(10)$ & $\begin{array}{l}.108 \\
(.194)\end{array}$ & $\begin{array}{l}-.015 \\
(.008)\end{array}$ & $\begin{array}{c}-.012 \\
(.013)\end{array}$ & $\begin{array}{l}.866 \\
(.179)\end{array}$ & .421 \\
\hline \multicolumn{6}{|l|}{$\begin{array}{l}\text { EG employment, } \\
\text { toughness not } \\
\text { instrumented: }\end{array}$} \\
\hline (11) & $\begin{array}{l}.100 \\
(.048)\end{array}$ & $\begin{array}{l}\cdots \\
\ldots\end{array}$ & $\begin{array}{l}\cdots \\
\cdots\end{array}$ & $\begin{array}{l}\cdots \\
\cdots\end{array}$ & 1.495 \\
\hline$(12)$ & $\begin{array}{l}.064 \\
(.075)\end{array}$ & $\begin{array}{r}-.020 \\
(.003)\end{array}$ & $\begin{array}{l}-.050 \\
(.003)\end{array}$ & $\begin{array}{l}\ldots \\
\ldots\end{array}$ & .169 \\
\hline$(13)$ & $\begin{array}{l}.283 \\
(.089)\end{array}$ & $\begin{array}{r}-.014 \\
(.004)\end{array}$ & $\begin{array}{c}-.025 \\
(.012)\end{array}$ & $\begin{array}{c}.405 \\
(.153)\end{array}$ & -.778 \\
\hline \multicolumn{6}{|l|}{$\begin{array}{l}\text { EG employment, } \\
\text { toughness } \\
\text { instrumented: }\end{array}$} \\
\hline (14) & $\begin{array}{l}.395 \\
(.145)\end{array}$ & $\begin{array}{c}-.014 \\
(.005)\end{array}$ & $\begin{array}{c}-.027 \\
(.012)\end{array}$ & $\begin{array}{l}.335 \\
(.143)\end{array}$ & -1.170 \\
\hline$(15)$ & $\begin{array}{c}.434 \\
(.166)\end{array}$ & $\begin{array}{c}-.013 \\
(.006)\end{array}$ & $\begin{array}{c}-.023 \\
(.012)\end{array}$ & $\begin{array}{l}.397 \\
(.159)\end{array}$ & -1.304 \\
\hline
\end{tabular}

Note.-Sample size is 162 . Heteroskedastic consistent standard errors are in parentheses. The serial correlation test is an $N(0,1)$ statistic for first-differenced panel data models as described in Arellano and Bond (1991). $\Delta \log$ (toughness) is instrumented using the log of real minimum wages dated $t, t-1, t-2$, and $t-3$ in rows 4,9 , and 14 and using the log of real minimum wages dated $t-2$ and $t-3$ in rows 5,10 , and 15 . Year dummies are included in all specifications.

In row 3 we control for sales growth (deflated by an aggregate price index to convert it to real terms) in our employment growth equation. It is evident that we cannot simply enter the contemporaneously dated sales variable as it is jointly determined with the dependent variable. 
Thus we instrument current sales growth using the log of real sales dated $t-2$ and $t-3$ (with the coefficient in the instrumentation equation allowed to vary in each cross section).${ }^{11}$ Controlling for sales appears to strengthen the effect of the minimum wage variable. While (instrumented) sales is significantly associated with employment, the coefficient on $\log$ (toughness) remains positive and gains in significance. There remains little comfort here for those who claim that Wages Council minimum pay rates were bad for employment in the 1975-92 time period.

One legitimate concern about our empirical work presented below is the potential endogeneity of the toughness variable, caused either by endogeneity of the average wage or the minimum itself. We can deal with the former by ensuring employment variations come through the minimum wage changes and not through average wage changes by instrumenting toughness using the minimum wage. In row 4 of table 3 we use the $\log$ of the real minimum wage dated $t, t-1, t-2$, and $t-3$ as instruments for the log of toughness. The coefficient on $\log$ (toughness) remains similar to that in row 3 but falls somewhat in significance. ${ }^{12}$

Dealing with the potential endogeneity of the minimum is somewhat more problematic. Ideally we would like to have an independent variable that exogenously shifts the minimum wage and has no direct effect on employment, but the only available instruments are lags of the minimum wage (the fact, discussed earlier, that the Wages Councils tended to be rather backward-looking suggests that lags may be sensible instruments). In row 5 of table 3 we therefore instrument toughness only using lags of the minimum wage dated $t-2$ and $t-3$. The coefficient on the log of toughness is similar to that in both rows 3 and 4 and remains positive and significant at the $10 \%$ level.

Hence, the specifications using our NES employment measure yield evidence that, counter to the conventional economic model, increases in Wages Council minimum rates of pay were not associated with reduced employment. There is no evidence whatsoever for the notion that minimum wage effects on employment were negative, and in statistical terms

\footnotetext{
${ }^{11}$ We instrument using the log of real sales dated $t-2$ and back since the MA(1) error induced by first-differencing the employment equation means that sales dated $t-1$ is not independent of the error term. We also tried simply using sales growth dated $t-2$ as a regressor, and this did not give qualitatively different results. Nor did allowing the instrumentation to vary by cross section make much difference to the nature of the reported results.

${ }^{12}$ Our results were very similar when we experimented by instrumenting toughness with different lags of the minimum and the average wage. For example, when we instrumented toughness with lags of the real minimum dated $t-1$ to $t-3$, the estimated coefficient (standard error) on log toughness was .341 (.199). When instrumenting with both lags of the real minimum and real average dated $t-1$ to $t-3$, the estimated coefficient (standard error) was .445 (.186).
} 
we can comprehensively reject a null hypothesis of an employment-minimum wage elasticity in the -.1 to -.2 range, which was cited as typical of the earlier U.S. time-series based evidence by Brown et al. (1982).

We conducted a large number of tests of the robustness of these results. First, we used total employee hours (from the NES) as our dependent variable. Rows 6-10 of table 3 report hours specifications analogous to those presented for NES employment. The coefficient on the minimum wage variable is estimated to be positive in all specifications, although the effects are generally less well determined.

Still concerned with possible discrepancies due to hours differences, we also considered whether our results could be explained by the undersampling of part-time workers in the NES. We did this in two ways. First, we included a variable measuring the minimum number of hours that had to be worked to earn more than the PAYE earnings limit. We constructed two variables of this type; in one we divided the weekly earnings limit by the minimum in the Wages Council concerned, while in the other we divided by average earnings. At no time did this variable alter the sign or magnitude of the estimated minimum wage effects.

We then considered whether our results hold for alternative measures of employment, and we report estimates using employment data from the Employment Gazette in rows 11-15 of table 3. Again, the results are very similar to those reported earlier. The impact of toughness on employment is positive and significant in row 9, the basic specification. When we control for demand shocks using sector dummies and sales growth, the coefficient on $\log$ (toughness) increases in magnitude and significance. This result is unchanged when we instrument toughness using the current value and lags of the real minimum (row 14) or just lags of the minimum (row 15).

On the basis of the results in table 3 we conclude that our findings are relatively robust across alternative employment measures and to various specification changes and robustness checks. However, despite the fact that the models reported in table 3 do not appear to suffer from model misspecification via omitted dynamics (see the serial correlation tests), there is a further issue of whether our results are contaminated by not considering the potential for dynamic minimum wage effects on employment (see Neumark and Wascher [1992], who argue that minimum wage effects on employment may persist across time periods). To this end we also report a set of dynamic employment functions that allow for minimum wage effects dated back to $t-2$ to affect employment.

We report six dynamic employment functions in table 4. The equations differ in their dependent variable (the two employment variables and the total employee hours variable) and in whether or not toughness is instrumented. While there are some differences in the nature of the estimated employment functions, they still paint an unambiguous pattern. Minimum wage effects are estimated to be positive and are even above the estimates 


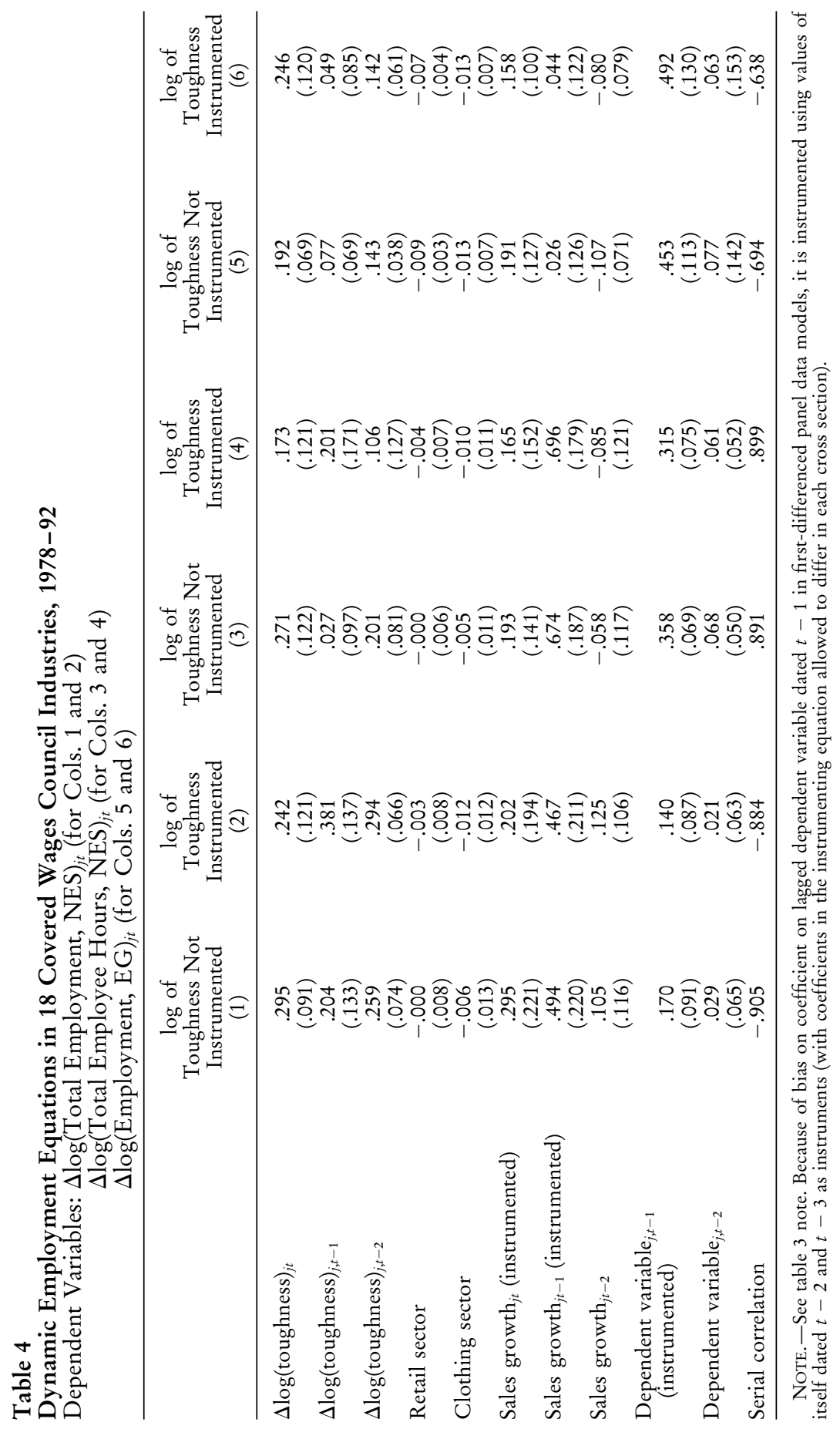


from static models in some specifications (suggesting, not unreasonably, that it takes some time for the supply of labor to increase). There remains no evidence of any negative impact of minimum wages on the employment patterns of Wages Council workers. Of course, it should be noted that we have investigated the effect of the Wages Councils on employment only in the affected industries; it is possible that employment in other industries is affected, but it seems rather implausible and unlikely to think that these indirect effects could overturn the direct effects. Irrespective of specification and data definition, the effect of minimum wages on employment is always estimated to be nonnegative and in many cases to be positive.

A final observation is that, if one takes the theoretical approach seriously, it implies a concave relationship between employment and minimum wages so that at lower levels of toughness one has the potential for positive minimum wage effects but the employment effect will be negative if the minimum wage is set high enough. One could investigate this in several ways, for example, by including nonlinearities in the toughness variable, by including initial levels of minimum wages, or by including linear splines. We chose the last route and estimated equations that model the relationship between employment and minimum wages as a piecewise linear function. Searching at .05 intervals produced a spline function with a single knot at .55 for the model with the lowest regression standard error, and we estimated the following model (standard errors in parentheses):

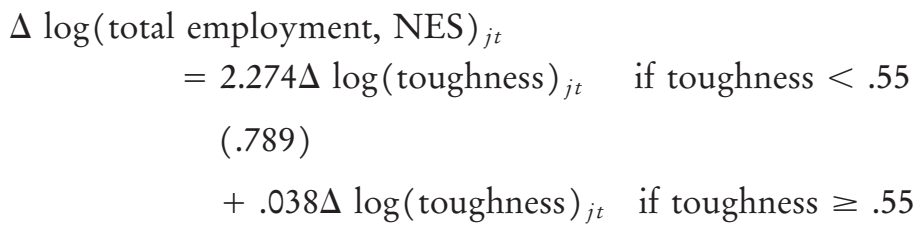

Minimum wage effects are positive (and significant) below toughness levels of .55 and insignificant thereafter. This estimated concave relationship is in line with the theory although we failed to find any evidence of the employment effect ever becoming negative, perhaps because toughness was never set a level high enough for this to be the case. Around one-fifth of the sample had toughness levels below . 55 (with 5 of the 12 councils having a toughness level lower than .55 in at least 1 year of the sample). Hence, there is some support (albeit rather limited) for the nonlinearity predicted by the theory. ${ }^{13}$

\footnotetext{
${ }^{13}$ Qualitatively similar, but statistically much weaker, results emerged if a squared term was included (i.e., a positive effect up to a point after which the relationship becomes negative).
} 
The overall tenor of these results provides a stark contrast with Kaufman's (1989) study of the employment effects of the Wages Councils, so it is probably worth commenting on differences between our study and his. First, there is a difference in the sample period used; most of his results are based on the 1970s. Second, the sample of Wages Council industries used are different. Kaufman concentrates on small manufacturing industries and excludes several of the large service-sector industries (notably retail and catering). Curiously, he also seems to have included two industries in his sample, jute and paper box, in which the Wages Councils were abolished in 1969, yet almost all his observations come from the 1970s. We believe that our sample covers the vast bulk of workers in Wages Council industries and so is likely to present a much more accurate picture of the effect of Wages Councils. Finally, there is a difference in methodology. Kaufman starts from the premise of the competitive model, then he estimates a labor demand curve as a relationship between employment and the average wage and then investigates the effect of the minimum on the average. This obviously constrains the minimum wage to have an effect on employment only through its effect on the average wage, something that is true only in the competitive model. This seems to prejudge the issue in a very specific way that probably accounts for why his results differ from ours.

\section{Conclusion}

In this article we have presented a model of the labor market that we have argued can be useful for thinking about the likely effects of minimum wages on the labor market when one is not sure a priori that minimum wages reduce employment. Using this theoretical framework and empirically implementing the approaches that we favor to examine the effect of minimum wages in Great Britain, we find strong evidence that they have compressed the distribution of earnings and no evidence that they have reduced employment, the latter being a result that would be regarded as anomalous in a competitive model, but one that can easily be explained in our framework.

Of course, the results reported here cast severe doubt on claims that the abolition of the Wages Councils in the 1993 Trade Union Reform and Employment Rights Bill could be justified on the grounds that they traditionally hindered employment. Furthermore, the experience of the Wages Council system while it operated, and the economic effects associated with council set minimum wages, should be of interest, particularly as the Labour government in Britain has legislated for the introduction of a national minimum wage in April 1999.

\section{References}

Arellano, Manuel, and Bond, Stephen. "Some Tests of Specification for Panel Data: Monte Carlo Evidence and an Application to Employment Equations." Review of Economic Studies 58 (April 1991): 277-98. 
Ashenfelter, Orley, and Smith, Robert. "Compliance with the Minimum Wage Law." Journal of Political Economy 87 (April 1979): 333-50.

Bernstein, Jared, and Schmitt, John. "Making Work Pay: The Impact of the 1996-97 Minimum Wage Increase." Washington, D.C.: Economic Policy Institute, 1998.

Brown, Charles; Gilroy, Curtis; and Kohen, Andrew. "The Effect of the Minimum Wage on Employment and Unemployment." Journal of Economic Literature 20 (June 1982): 487-528.

Brown, Charles, and Medoff, James. "The Employer Size-Wage Effect." Journal of Political Economy 97 (October 1989): 1027-59.

Burdett, Kenneth, and Mortensen, Dale. "Wage Differentials, Employer Size and Unemployment." International Economic Review 39 (May 1998): 257-74.

Card, David. "Using Regional Variations in Wages to Measure the Effects of the Federal Minimum Wage." Industrial and Labor Relations Review 46 (October 1992): 22-37. (a)

- "Do Minimum Wages Reduce Employment? A Case Study of California, 1987-89." Industrial and Labor Relations Review 46 (October 1992): 38-54. (b)

Card, David; Katz, Lawrence; and Krueger, Alan. "Comment on David Neumark and William Wascher, 'Employment Effects of Minimum and Sub-minimum Wages: Panel Data on State Minimum Wage Laws.' " Industrial and Labor Relations Review 47 (April 1994): 487-96.

Card, David, and Krueger, Alan. "Minimum Wages and Employment: A Case Study of the Fast Food Industry in New Jersey and Pennsylvania." American Economic Review 84 (September 1994): 772-93.

- Myth and Measurement: The New Economics of the Minimum Wage. Princeton, NJ: Princeton University Press, 1995.

- "A Re-analysis of the Effect of the New Jersey Minimum Wage Increase on the Fast Food Industry Using Representative Payroll Data." Cambridge, MA: National Bureau of Economic Research, 1998.

Deere, Donald; Murphy, Kevin M.; and Welch, Finis. "Employment and the 1990-1991 Minimum Wage Hike." American Economic Review Papers and Proceedings 85 (May 1995): 232-37.

Dickens, Richard; Gregg, Paul; Machin, Stephen; Manning, Alan; and Wadsworth, Jonathan. "Wages Councils: Was There a Case for Abolition?" British Journal of Industrial Relations 31 (December 1993): 515-29.

Dickens, Richard; Machin, Stephen; and Manning, Alan. "Minimum Wages and Employment: A Theoretical Framework with an Application to the Wages Councils." In "Low Pay and Minimum Wages." edited by Stephen Bazen and Gilbert Benhayoun. International Journal of Manpower, 15, special issue (1994): 26-48.

Dickens, Richard; Machin, Stephen; Manning, Alan; Metcalf, David; Wadsworth, Jonathan; and Woodland, Stephen. "Minimum Wages and UK Agriculture." Journal of Agricultural Economics 49 (January 1995): 1-19.

Dickens, Richard, and Manning, Alan. "After Wages Councils." Nerw Economy 2 (Winter 1995): 223-27. 
Dickens, William, and Katz, Lawrence. "Interindustry Wage Differences and Industry Characteristics." In Unemployment and the Structure of Labor Markets, edited by Kevin Lang and Jonathan Leonard. Oxford: Blackwell, 1987.

Dixit, Avinash, and Stiglitz, Joseph. "Monopolistic Competition and Optimum Product Diversity." American Economic Review 67 (June 1977): 297-308.

Katz, Lawrence, and Krueger, Alan. "The Effect of the Minimum Wage in the Fast Food Industry." Industrial and Labor Relations Review 46 (October 1992): 6-21.

Kaufman, Roger. "The Effects of Statutory Minimum Rates of Pay on Employment in Great Britain." Economic Journal 99 (December 1989): 1040-53.

Kim, T., and Taylor, L. J. "The Employment Effect in Retail Trade of California's 1988 Minimum Wage Increase.” Journal of Business and Economic Statistics 13 (April 1995): 175-82.

Machin, Stephen, and Manning, Alan. "Minimum Wages, Wage Dispersion and Employment: Evidence from the UK Wages Councils." Industrial and Labor Relations Review 47 (January 1994): 319-29.

_. "Employment and the Introduction of a Minimum Wage in Britain." Economic Journal 106 (May 1996): 667-76.

Machin, Stephen; Manning, Alan; and Woodland, Stephen. “Are Workers Paid Their Marginal Product? Evidence from a Low Wage Labour Market." Discussion Paper no. 93-09. London: University College London, 1993.

MacLeod, W. Bentley, and Malcomson, James. "Investments, Hold-Up and the Form of Market Contracts." American Economic Review 83 (September 1993): 811-37.

Neumark, David, and Wascher, William. "Employment Effects of Minimum and Sub-minimum Wages: Panel Data on State Minimum Wage Laws." Industrial and Labor Relations Review 46 (October 1992): $55-81$.

. "The Effect of New Jersey's Minimum Wage Increase on FastFood Employment: A Re-evaluation Using Payroll Records.” Photocopied. East Lansing: Michigan State University, 1995.

Nickell, Stephen, and Wadhwani, Sushil. "Insider Forces and Wage Determination." Economic Journal 100 (June 1990): 496-509.

Sullivan, Daniel. "Monopsony Power in The Market for Nurses." Journal of Law and Economics 32 (October 1989): S135-S178. 